\title{
PRIZE AND SCHOLARSHIP PROGRAMMES
}

\author{
L.F.S. Ritcey
}

The Canadian Mathematical Congress has always been interested in the problem of arousing more interest in mathematics among high school students and of aiding good students to pursue university studies. Only during the last few years has it sponsored mathematical competitions and awarded scholarships and/or prizes to outstanding students. These competitions have been exceedingly successful. The number of candidates has exceeded expectations in several provinces and the prestige accorded to the winners has helped to emphasize mathematics in the minds of all students. In several schools mathematics clubs have been formed. The competitions have also enabled the Congress to give outstanding students information about the opportunities available in the mathematical fields with the hope that more will be encouraged to enter the fields of research and teaching. They have been valuable from the financial side since they have resulted in more publicity for all our activities. This is important from the point of view of contributors to the general funds.

In the six provinces where the Congress sponsors a competition the examinations have been of the long answer type and are carried on in cooperation with the departments of education. The choice of the type of examination is entirely in the hands of the local committees who have favoured this type, particularly for the awarding of scholarships. It is true that this involves more time and expense but at the present time these committees are of the opinion that the results are well worth the additional time and expense.

A national competition was suggested at the Council meeting in New Brunswick last August but this does not appear to be feasible at the present time. It would, however, be possible to use the same examination in provinces where the competitions are now operating at the same level. This would save a certain amount of duplication of effort and might produce some interesting results.

A summary of these programmes is given in the following table and a more detailed description for each province follows. All scholarships and bursaries are paid after the winning candidate has registered at a university. 


\begin{tabular}{|c|c|c|c|}
\hline Province & $\begin{array}{l}\text { Number of } \frac{\mathrm{Can}}{\text { didates in }} 1959 \\
\text { didat }\end{array}$ & Types of Awards & $\begin{array}{l}\text { Total } \\
\text { Amount }\end{array}$ \\
\hline Nova Scotia & 104 Grade XII & Scholarships & $\$ 3900$ \\
\hline New Brunswick & 128 Grade XII & Scholarships & 3800 \\
\hline Quebec & $\begin{array}{c}620 \text { Grades XI } \\
\text { and XII }\end{array}$ & $\begin{array}{l}\text { Prizes } \\
\text { Scholarships \& } \\
\text { Bursaries }\end{array}$ & $\begin{array}{r}750 \\
1500\end{array}$ \\
\hline Ontario & 630 Grade XIII & $\begin{array}{l}\text { Prizes } \\
\text { Scholarships }\end{array}$ & $\begin{array}{l}1350 \\
2400\end{array}$ \\
\hline Manitoba & 730 Grade XI & $\begin{array}{l}\text { Prizes } \\
\text { Bursaries }\end{array}$ & $\begin{array}{l}770 \\
800\end{array}$ \\
\hline Alberta & 225 Grade XII & Scholarships & 2200 \\
\hline
\end{tabular}

Nova Scotia. Six scholarships of $\$ 400$ each are awarded on the basis of an examination set by a local committee. The examination is written in June at the end of the provincial examination period and is distributed and conducted by the department of education. These scholarships may be renewed in whole or in part depending upon the funds available, with consideration given to academic standing and financial need. Contributions from Nova Scotia in nearly all cases are used only for these scholarships and are not included in the general funds of the Congress. These scholarships have been awarded for the past six years on the basis of an examination in Grade XII mathematics, the senior matriculation level. Because many good students enter the universities after Grade XI, a change to Grade XI, the junior matriculation level, will be initiated in 1960 . The Congress also plans to initiate a prize programme in Grade $\mathrm{XI}$ in addition to the scholarships, in 1960 .

New Brunswick. A scholarship programme is offered in Grade XII which is the junior matriculation level. Otherwise it is identical with the Grade XII programme in Nova Scotia.

Quebec. The Congress instituted prizes and scholarships based upon a special examination for the first time in 1959. These awards were made under the direction of a committee made up of representatives of McGill University, University of Montreal, the Protestant School Board, the Catholic School Board and in addition, representatives of industry and of the Canadian Mathematical Congress, to students in Grade XI of the English-speaking schools and in Grade XII of the Frenchspeaking schools.

Six hundred and twenty students wrote the examination, of whom about half were from each language group. The examination was given in both languages. For the first year the com- 
petition was restricted to the island of Montreal, but in view of its success, the Congress expects to extend it to the whole province in 1960 .

Prizes of $\$ 25$ each were awarded in each of twenty dis tricts or groups of schools. In addition, two overall prizes of $\$ 100$ and $\$ 50$ were awarded to the first and second ranking candidates.

Scholarships of $\$ 250$ each were awarded to each of the four highest ranking candidates in the name of the donor, the Sun Life Assurance Company of Canada, and $\$ 100$ to each of the next wo candidates.

Ontario. For the past two years prizes have been offered to outstanding candidates in the problems paper of Grade XIII. Until recently, a comparatively small number of students presented themselves for this paper, but the offering of prizes seemed to create a great deal of interest and this year over six hundred candidates wrote the examination. A prize of $\$ 50$ was offered in each of nineteen districts in the province and four overall prizes of $\$ 100$ each.

In Ontario there appeared to be more need of financial assistance to meet the expenses of the required period in the Ontario College of Education. On this account the Congress for several years has offered eight scholarships of $\$ 300$ for this purpose, two being allotted to graduates of the University of Toronto and one each to the six other universities in the province.

The Congress also assists in the expenses of the competition conducted by the American Mathematical Association and the Canadian Association of Actuaries, which is open to students in Grades XI, XII and XIII.

Manitoba. A prize programme has been conducted for the past three years on the basis of an examination at the Grade $X I$ level (junior matriculation). Twelve prizes of $\$ 40$ each have been awarded in each of twelve districts in the province and four prizes of $\$ 100, \$ 80, \$ 60$, and $\$ 50$. respectively to the four highest ranking candidates in the province. In addition to these awards, a number of bursaries of $\$ 100$ each are awarded on the recommendation of the local committee. The Congress also awards a scholarship of $\$ 200$ to the student in the third year of the honours mathematics course who attains the highest standing.

Alberta. Six scholarships are awarded to the highest candidates on the basis of a special examination in Grade XII. The scholarships are of varying amounts ranging from $\$ 250$ to $\$ 500$ several of which are in the names of the donors, as follows: 
Congress Scholarship-...

Carl and Nola Nickle

Foundation Scholarship -.............. $\$ 400$

Congress Scholarship-...

L.T. Melton Real Estate Ltd.

Scholar ship-... . . . . . . . $\$ 350$

Samuel S. Guttman Family

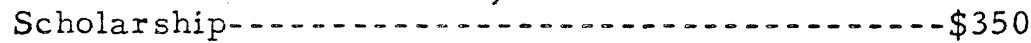

Haddin, Davis and Brown Ltd.

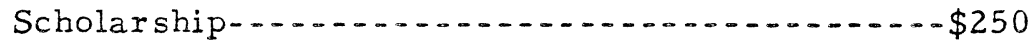

